\title{
Communication
}

\section{Organic Growth Theory for Corporate Sustainability}

\author{
Ahmad Karnama ${ }^{1, *(1)}$ and Ricardo Vinuesa $2, *$ (1) \\ 1 Aban Foundation, 18765 Stockholm, Sweden \\ 2 SimEx/FLOW, Engineering Mechanics, KTH Royal Institute of Technology, 10044 Stockholm, Sweden \\ * Correspondence: ahmad.karnama@aban.foundation (A.K.); rvinuesa@mech.kth.se (R.V.)
}

Received: 7 August 2020; Accepted: 8 October 2020; Published: 15 October 2020

\begin{abstract}
This paper introduces a theory for the evolution of corporates in which the growth and sustainability strategies are developed simultaneously. Since the introduction of corporate sustainability, it has been seen an extra cost for risk mitigation and making "compensating" positive impact. The world has reached a tipping point of volatility, mainly due to climate change but also due to the emergence of COVID-19, therefore the applicability of existing corporate structures is under question and this poses high risk to the existence of our planet. On the other hand, the technology cost for sustainable investment has reached parity in comparison with non-sustainable alternatives. Therefore, our proposed Organic Growth Theory introduces a step-by-step approach so that corporates can grow and be profitable without compromising the ability of future generations to meet their needs. It is concluded that a new structure for corporates, called founcorps, would be required to direct corporates to evolve into being a responsible legal entity.
\end{abstract}

Keywords: corporate sustainability strategy; corporate growth strategy; Maslow pyramid; Organic Growth Theory; corporate social responsibility; corporate responsibility; sustainability

\section{Introduction}

The role of corporates in sustainable development is inevitable and critical [1-3]. The challenges associated with developing corporate-sustainability strategies have received some attention in the literature over the past decade [4-8]. It has been argued that in order to truly incorporate sustainability into corporate decision making and culture, it is essential to develop new governance strategies to fully involve stakeholders [9], so as to positively impact sustainability from the three main perspectives of society, economy and environment $[10,11]$. Recent studies have highlighted the importance of five key corporate sustainability practices (perseverance, resilience development, moderation, geosocial development and sharing) to obtain commitment from employees so as to realize the sustainable-corporate vision [12]. Other studies have focused on the sustainable interaction of corporates with the community, advocating for long-term mutually beneficial commitments beyond philanthropic donations [13]. However, one aspect that has not received the same level of attention in literature is the way in which corporates grow, and in particular, how to ensure that this process is conducted in a sustainable manner. This is the main topic covered in the present study.

The conventional means of corporate growth are mainly based on inorganic methods and focuses on mergers and acquisitions (M\&A) [14]. This is an old-fashioned method for growth among corporates with access to large capital. Instead of taking the required steps to grow (i.e., through the progressive development of a basis to grow innovation, creating a positive impact and increasing the number of employees organically), they decide to grow rapidly via M\&A. This approach is designed for a less diversified, less global economy. There are two main problems associated with M\&A as an approach to grow: 
- Post-M\&A interdepartmental integration affects the efficiency and effectiveness of new product development (NPD), thus affecting innovation, given the collateral challenges in corporate cultural integration [15].

- It fails to take into account the challenge (and potential consequences) of weak corporate culture assimilation, which is nowadays of high priority for corporates given recruitment costs, over/under qualified labor force and the rise of employment alternatives in the labor market, among others [16], such as energy [17].

In this traditional model, corporates buy smaller companies around them in an attempt to grow. In this way, not only do they negatively influence the competition in the market and reduce the quality of the service [18], but they also create a toxic internal corporate environment with conflicts of interests, unfair competitions, and dense internal politics [19]. This environment will not develop and retain qualified employees, but rather it will support and maintain employees with high political skills. This will eventually lead to reduced quality of service, social losses, and even losses for the corporate itself.

It is noteworthy to mention other rather innovative approaches to corporate growth, as exhibited by Apple (who uses the so-called Ansoff matrix [20]), combining four growth strategies (market penetration, product development, market development, diversification), which by design give rise to innovation. In other words, Apple develops internal capabilities by investing in accelerating innovation [21]. However, the missing point is how to grow without compromising the future generation. In the following, we describe and discuss our proposed approach for sustainable corporate growth, i.e., what we call the Organic Growth Theory (OGT).

The aim of this study is to define our Organic Growth Theory (OGT), which introduces a step-by-step approach so that corporates can grow and be profitable without compromising the ability of future generations to meet their needs. The article is structured as follows: in Section 2 we introduce the background and theoretical/scientific justification of OGT, in Section 3 we define the OGT, and discuss its connection with the concept of ecological thinking and the hierarchy of needs by Maslow. In Section 4, we provide an extensive discussion of the relationship between OGT and corporate social responsibility. Finally, in Section 5, we give our conclusions and highlight our suggested directions of future development.

\section{Background}

The Industrial Revolution, known as the transition to new manufacturing processes in Europe and the United States [22], occurred in the period from about 1760 to sometime between 1820 and 1840 [23]. This transition included going from hand production methods to machines, new chemical manufacturing and iron production processes, the increasing use of steam power and waterpower, the development of machine tools and the rise of the mechanized factory system [24]. This was inevitable as cause of an unprecedented rise in the rate of population growth and the need for goods at any price. This is essentially when the idea of economies of scale was raised [25]. However, since the increase in climate change awareness [26] and challenges with big corporates [27], people have started to ask if there is any hidden cost in economies of scale [28,29]? This question is discussed in more detail in this section of this paper.

The simple definition of economies of scale is doing things more efficiently with increasing size [30]. Common sources of economies of scale are purchasing (bulk buying of materials through long-term contracts), managerial (increasing the specialization of managers), financial (obtaining lower-interest charges when borrowing from banks and having access to a greater range of financial instruments), marketing (spreading the cost of advertising over a greater range of output in media markets), and technological (taking advantage of returns to scale in the production function) [31]. Each of these factors reduces the long run average costs (LRAC) of production by shifting the short-run average total cost (SRATC) curve down (lower cost) and to the right (more production) [32]. This is a simple example of how the halo effect [33] can bias individuals and even societies for decades [34]. 
The halo effect (sometimes called the halo error), one important type of cognitive bias, is the tendency for positive impressions of a person, company, brand or product in one area to positively influence one's opinion or feelings in other areas [35]. The halo effect occurs when a single aspect dazzles us and affects how we see the full picture [36]. This is how the lower cost of products in economies of scale would dazzle people from seeing its considerable drawbacks. The claimed advantages of economies of scale and its drawbacks are described in Table 1.

Table 1. Claimed advantages and drawbacks of economies of scale [37].

\begin{tabular}{|c|c|c|}
\hline & Claimed Advantages & Drawback \\
\hline Purchasing & $\begin{array}{l}\text { Bulk buying of materials through } \\
\text { long-term contracts }\end{array}$ & $\begin{array}{l}\text { Promote intra-giants deals with no place } \\
\text { for local and smaller businesses to } \\
\text { compete }\end{array}$ \\
\hline Managerial & Increasing the specialization of managers & $\begin{array}{c}\text { Politics is above leadership skills and } \\
\text { technical expertise }\end{array}$ \\
\hline Financial & $\begin{array}{c}\text { Lower-interest borrowing from banks } \\
\text { and access to a greater range of financial } \\
\text { instruments }\end{array}$ & $\begin{array}{l}\text { Negative influence on the environment } \\
\text { and local businesses and jobs }\end{array}$ \\
\hline Marketing & $\begin{array}{l}\text { Spreading the cost of advertising over a } \\
\text { greater range of output in media markets }\end{array}$ & $\begin{array}{l}\text { Inappropriate marketing campaigns to } \\
\text { promote consumerism with literally any } \\
\text { tool (women, kids or etc.) }\end{array}$ \\
\hline Technological & $\begin{array}{l}\text { Taking advantage of returns to scale in } \\
\text { the production function }\end{array}$ & $\begin{array}{l}\text { Negative influence on smaller } \\
\text { companies, local production and } \\
\text { entrepreneurship. Slow and costly } \\
\text { technological development. }\end{array}$ \\
\hline
\end{tabular}

There is no doubt that economies of scale helped societies to grow and it was the single way to cope with the population growth $[38,39]$. However, there are many drawbacks that endanger our world. People would not need products at any cost while the hidden costs are causing existential threat to all of us [37,40,41]. Corporates needs to evolve to be centered to ecologism [42,43] and altruism [44]. This evolution already happened among corporates mainly through corporate social responsibility (CSR) [45] but this needs to be addressed in much more structured way, and it will be described in this paper by introducing and discussing Organic Growth Theory (OGT).

OGT was first introduced in June 2019 [46], where numerous engagement and inputs were received from different stakeholders in sustainability areas around the world. Based on those engagements and inputs, in the next section of this paper, OGT will be discussed in more detail.

\section{Organic Growth Theory (OGT)}

A forward-thinking way of approaching corporate growth would entail a clear vision for impact and a strategy that supports such a vision. In this model, relevance, measurability and scalability would be used as guiding principles. Similarly, impact-driven growth would require corporates to put in place effective transparency mechanisms to leverage the benefits of this modern approach. Our proposed OGT has three main principles:

1. Create meaningful reasons and impactful visions for growth.

2. Take a step-by-step approach based on the hierarchy of needs by Maslow [47,48], and a phase-by-phase process based on the concept of ecological thinking articulated by Code in [49], guiding the growth strategy.

3. Increase output by focusing more on internal measures.

In the OGT framework, we denote the next generation of corporates as foundation corporates (founcorps for brevity). Founcorps focus on bringing meaningful reasons and impactful visions to a corporate. As mentioned above, the proposed OGT approach is based on two well-known theories: Maslow's hierarchy of needs [50] and the concept of ecological thinking [49]. The former is a behavioral 
motivation theory in psychology, and we will consider the more recent version comprising a seven-tier model of human needs [51], often depicted as hierarchical levels within a pyramid [52], as illustrated in Figure 1.

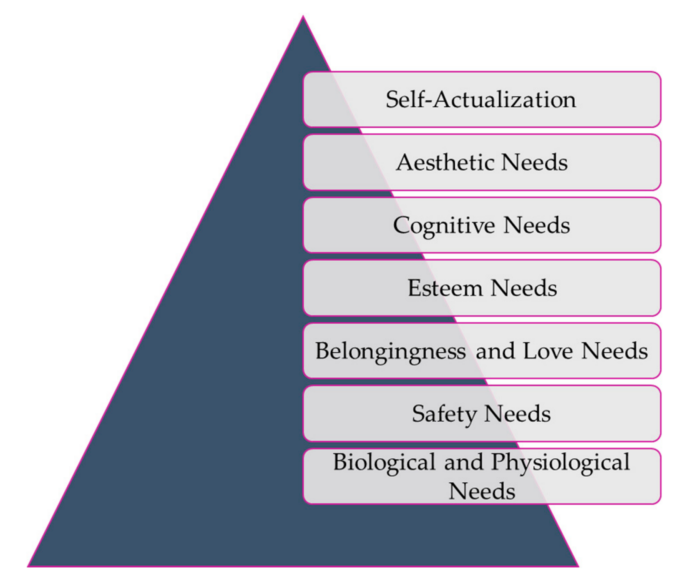

Figure 1. Schematic representation of Maslow's seven-tier hierarchy of needs [51].

Needs further down in the hierarchy must be satisfied before individuals can attend to needs higher up. From the bottom of the hierarchy upwards, the needs are biological and physiological, safety, love and belonging, esteem, cognitive, aesthetic and self-actualization. These steps have been translated to the corporate world, as displayed in Table 2.

Table 2. Relation between examples of needs highlighted by Maslow for individuals [51] and their equivalent in corporate

\begin{tabular}{|c|c|c|c|}
\hline & Maslow Pyramid & Personal & Corporate \\
\hline 1 & Physiological Needs & $\begin{array}{l}\text { Oxygen, Food, Water, } \\
\text { Sex, Sleep, Warmth }\end{array}$ & $\begin{array}{c}\text { One Employee, Product/Service, } \\
\text { Business Strategy, Small Funds, } \\
\text { Workspace, Stationery, Phone, } \\
\text { Computer, Internet }\end{array}$ \\
\hline 2 & Safety Needs & $\begin{array}{l}\text { Protection, Security, } \\
\text { Order, Law, Limit, } \\
\text { Stability }\end{array}$ & $\begin{array}{l}\text { Stream of Revenue, Multiple Employees, } \\
\text { Steady Retention Rate, Office Space }\end{array}$ \\
\hline 3 & $\begin{array}{l}\text { Belongingness/Love } \\
\text { Needs }\end{array}$ & $\begin{array}{l}\text { Family, Affection, } \\
\text { Relationships }\end{array}$ & Employee Relations, Investors, Clients \\
\hline 4 & Esteem Needs & $\begin{array}{l}\text { Achievement, Status, } \\
\text { Responsibility, } \\
\text { Reputation }\end{array}$ & Brand Recognition, Partnerships \\
\hline 5 & Cognitive Needs & $\begin{array}{l}\text { Knowledge, meaning, } \\
\text { self-awareness }\end{array}$ & $\begin{array}{c}\text { IPO (Initial Public Offering), Press } \\
\text { Coverage }\end{array}$ \\
\hline 6 & Aesthetic Needs & Beauty, balance & Corporate Social Responsibility \\
\hline 7 & Self-Actualization & $\begin{array}{l}\text { Personal Growth, } \\
\text { Fulfillment }\end{array}$ & Sustainability, Corporate Citizenship \\
\hline
\end{tabular}

For corporates, it starts from basic needs for strategy and funds before leading to sustainability, corporate citizenship and corporate social responsibility (CSR). An interesting example illustrating this point is the case of Aramco [53], the largest oil company in the world, since their entire CSR focus is on corporate citizenship. While all the CSR activities are appreciated and invaluable, it is important to evolve corporate structures to grow in a responsible way. The growth path is described in Organic Growth Theory (OGT) and the goal is that the corporates should evolve to be responsible entities called founcorps (foundation corporates). 
In the OGT framework, the seven steps depicted in Table 2 need to be repeated in three different phases until a company can truly become a founcorp. These three phases are based on the concept of ecological thinking [49], and they are illustrated in Figure 2.

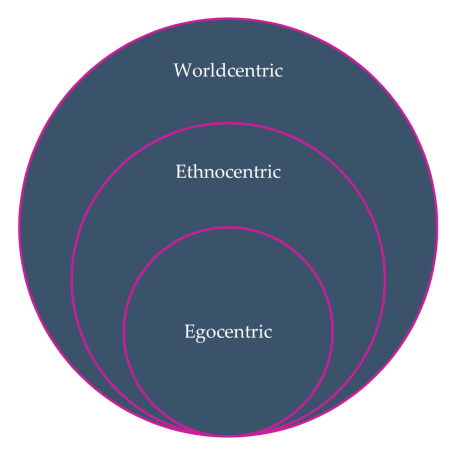

Figure 2. Representation of the three phases within ecological thinking [49].

Ecological thinking is a natural way for responsible corporates to work and grow. It allows the concerned corporates to be part of the natural rebalancing process in the lives of people and nature [54]. It also enables corporate concerns to serve the entire interdependent web of nature and life. Furthermore, it makes the corporate concerns valuable to people and nature $[55,56]$. This widening of identity $[57,58]$ is divided into three phases for both corporate and individuals in ecological thinking, as summarized in Table 3.

Table 3. Identity widening in ecological thinking (individual and corporate).

\begin{tabular}{lccc}
\hline & Egocentric & Ethnocentric & Worldcentric \\
\hline Individual Identity & Me & My Group & All of us \\
Corporate Identity & Our corporate & Our corporates & All of us \\
\hline
\end{tabular}

As shown in Table 3, ecological thinking in the corporate world involves an expansion of corporate identity in the way in which corporates are seen in relation to the world. This makes the corporate evolve from being seen only as a corporation (egocentric), to seeing all the corporations as a community (ethnocentric), and eventually seeing all the corporations as part of one world (worldcentric).

The corporates can evolve by passing the seven steps of Maslow's pyramid and stages of ecological thinking, while at each stage the values should be redefined. To summarize, the nine steps required to become a founcorp are shown in Figure 3.

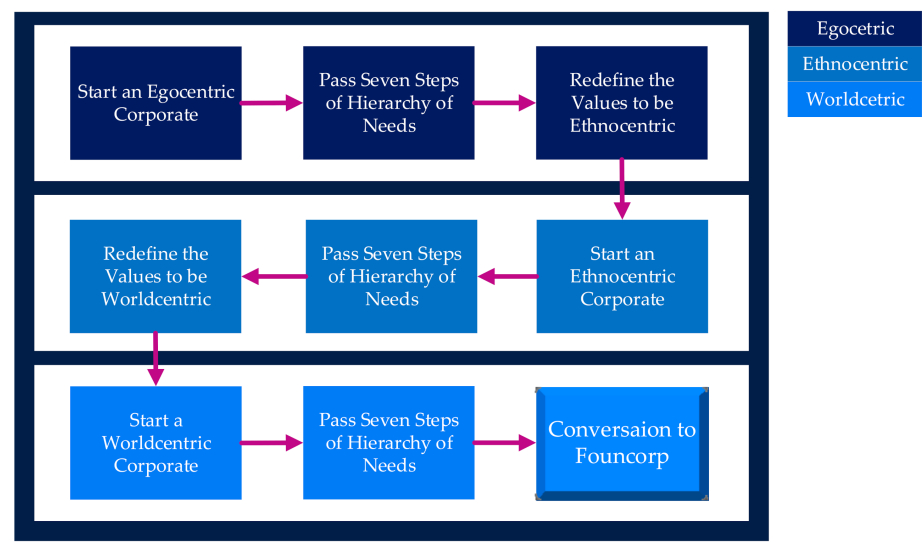

Figure 3. Summary of the 9 steps required for a corporate to become a founcorp, in the proposed Organic Growth Theory (OGT) framework. 
As shown in Figure 3, it is necessary to take the seven steps of Maslow's hierarchy of needs [51] to grow. However, this is not enough. Those seven steps need to be taken in line with the three phases of ecological thinking [49]. These steps and phases constitute what we define as a founcorp, which is world centric with meaningful reasons and impactful visions for growth. Three areas are relevant in the context of ecological thinking: environment, economy and society. These can be viewed as the corporate responsibility for environmental remediation of polluted natural resources, economic valuation of ecosystems, as well as deep environmental education to develop well-informed and environmentally aware citizens. These are very important areas of development in order to become a founcorp.

\section{Discussion}

The development of sustainable societies is influenced by and affects corporate sustainability. The interdependence of these areas is evident, as discussed in [59]. There is high demand for corporates to evolve towards becoming responsible entities in societies and the Organic Growth Theory introduces a step-by-step approach to achieve that goal. As briefly noted above, this notion is closely connected with that of corporate social responsibility (CSR), which implies positive impact of corporations on society and the environment [60]. There is on-going work assessing the extent to which CSR may be used to engage stakeholders, which is the idea of promoting positive, sustainable values in the context of social media [61]. Another area where CSR may have a positive impact, and where the ecological-thinking steps within OGT become very relevant, is that of tourism and its impact on the local residents [62,63]. Employee commitment may be positively affected by an adequate CSR approach [64], as also discussed in Table 2 for OGT. Note that the actual economical impact of adopting CSR measures is still under investigation [65], but certain critical aspects such as adapting corporate procedures to the needs of people with disabilities are absolutely essential for OGT [66]. Other noteworthy dimensions are CSR adaptation to countries under development [66,67], and adaptation of OGT concepts to concrete areas, for instance libraries [68] or the construction sector [69].

The role of data handling in this evolution is inevitable. The current revolution of artificial intelligence (AI), which has the potential to highly benefit society, has also revealed the numerous hazards associated with the irresponsible use of the technology [11]. Although profiling and automated decision-making algorithms have the potential to provide enormous opportunities to corporates, it is of utmost important to follow ethical and transparent guidelines in these applications [70]. This particular point becomes particularly relevant in the context of public emergencies, such as that of the COVID-19 pandemic [71]. Therefore, we argue that a transparent and ethical handling of data and AI-based tools is an integral aspect for a company to become a founcorp. In a related note, a responsible CSR regarding technology adoption within the company may have a positive impact on employee motivation [72].

The needs of a founcorp are essential to not only grow but also to make our growth organic and produce prosperous societies. This is also connected to the fact that traditional management by objectives (MBO) has been found to be flawed [73]. The role of governments is to empower founcorps by prioritizing the focus areas for founcorps. We argue that this can be a replacement for current tax payments where, instead of paying tax, founcorps can invest their revenue to bring about social value. This novel concept builds on current tax-exemption schemes currently applied to businesses creating social value in certain European countries.

\section{Conclusions and Future Research Directions}

Corporations, which are a direct consequence of capitalism [74,75], are the intermediate entities between governmental institutions and the citizens, there is significant bilateral influence between corporations and both groups. Corporations have a very large impact towards the development of people, serving us to increase our life quality and to enable the evolution of societies. However, corporations have also done their own share of harms and climate change is the largest and most dangerous one. We have now reached a tipping point, and this harm creates an existential threat to all 
of us. For corporations to be able to do any business in the future, we need to integrate the fruits of capitalism (corporations) into our societies to save our lives and further increase the life quality of future generations.

Furthermore, the world has reached a tipping point of volatility, mainly due to climate change but also through the emergence of COVID-19 [71]. Thus, the applicability of existing corporate structures is under question, and this poses high risk to the existence of our planet. On the other hand, the technology cost for sustainable investment has similar levels to those of non-sustainable alternatives.

Adam Smith (1723-1790) [76] is often identified as the father of modern capitalism. In his famous quote, he says that "It is not very unreasonable that the rich should contribute to the public expense not only in the portion of their revenue but something in more than that portion". A very relevant public cost nowadays is the harm caused by carbon emissions and climate change, and corporations need to contribute to tackle that threat with more than a portion of their revenues. There is a need for structural change on how corporations operate. This means that the corporations need to evolve so that their growth and the global sustainability strategies are compatible and synergistic.

The approach proposed in this paper, Organic Growth Theory, would define a structural change to address the above issues. Organic Growth Theory is a step-by-step approach so that corporates can continue growing and being profitable without compromising the ability of future generations to meet their needs. A new paradigm for corporates, called foundation corporates (founcorps), would be needed to direct corporates to evolve into being a responsible legal entity and to become integrated into our societies.

The shift to ecologism (Organic Growth Theory) from one of the main results of capitalism (corporates) is a necessity. With the current pace of increasing awareness of the climate-change threat and the fast changes in carbon-emission regulations, the decision for corporates between adoption of organic growth theory or accepting the consequences will come soon. Future work will be devoted to further developing each step in the Organic Growth Theory, defining concrete actions for the evolution of corporations.

Author Contributions: Conceptualization, A.K.; methodology, A.K.; formal analysis, A.K. and R.V.; writing — original draft preparation, A.K.; writing — review and editing, R.V. and A.K. All authors have read and agreed to the published version of the manuscript.

Funding: The authors would like to thank Royal Institute of Technology and Aban Foundation for funding the time of the authors to be able to publish this paper.

Acknowledgments: The authors acknowledge Grace Avila Casanova for her insightful comments on this manuscript.

Conflicts of Interest: The authors declare no conflict of interest.

\section{References}

1. Agarwal, N.; Gneiting, U.; Mhlanga, R. Raising the Bar: Rethinking the Role of Business in the Sustainable Development Goals; Oxfam: Oxford, UK, 2017.

2. Harari, Y.N. Homo Deus: A Brief History of Tomorrow; Random House: New York, NY, USA, 2016.

3. Harari, Y.N. Sapiens: A Brief History of Humankind; Random House: New York, NY, USA, 2014.

4. Linnenluecke, M.K.; Griffiths, A. Corporate sustainability and organizational culture. J. World Bus. 2010, 45, 357-366. [CrossRef]

5. de Lange, D.E.; Busch, T.; Delgado-Ceballos, J. Sustaining sustainability in organizations. J. Bus. Ethics 2012, 110, 151-156. [CrossRef]

6. Kok, A.M.; de Bakker, F.G.; Groenewegen, P. Sustainability struggles: Conflicting cultures and incompatible logics. Bus. Soc. 2019, 58, 1496-1532. [CrossRef]

7. Scherer, A.G.; Palazzo, G. Toward a political conception of corporate responsibility: Business and society seen from a Habermasian perspective. Acad. Manag. Rev. 2007, 32, 1096-1120. [CrossRef]

8. Hanke, T.; Stark, W. Strategy development: Conceptual framework on corporate social responsibility. J. Bus. Ethics 2009, 85, 507. [CrossRef] 
9. Ashrafi, M.; Adams, M.; Walker, T.; Magnan, G. How corporate social responsibility can be integrated into corporate sustainability: A theoretical review of their relationships. Int. J. Sustain. Dev. World Ecol. 2018, 25, 672-682. [CrossRef]

10. Stockholm Resilience Centre's (SRC) Contribution to the 2016 Swedish 2030 Agenda HLPF Report; Stockholm University: Stockholm, Sweden, 2017.

11. Vinuesa, R.; Azizpour, H.; Leite, I.; Balaam, M.; Dignum, V.; Domisch, S.; Felländer, A.; Langhans, S.D.; Tegmark, M.; Nerini, F.F. The role of artificial intelligence in achieving the Sustainable Development Goals. Nat. Commun. 2020, 11, 1-10. [CrossRef]

12. Kantabutra, S.; Ketprapakorn, N. Toward a theory of corporate sustainability: A theoretical integration and exploration. J. Clean. Prod. 2020, 270, 122292. [CrossRef]

13. Tracey, P.; Phillips, N.; Haugh, H. Beyond philanthropy: Community enterprise as a basis for corporate citizenship. J. Bus. Ethics 2005, 58, 327-344. [CrossRef]

14. Lynch, J.G.; Lind, B. Escaping merger and acquisition madness. Strategy Leadersh. 2002, 30, 5-12. [CrossRef]

15. Chen, C.-H.; Chang, Y.-Y.; Lin, M.-J.J. The performance impact of post-M\&A interdepartmental integration: An empirical analysis. Ind. Mark. Manag. 2010, 39, 1150-1161.

16. Nandi, S.; Nandi, M.L. Revisiting Activity Theory: A Useful Framework for Improving Post-Acquisition Integration Effectiveness. Vilakshan: XIMB J. Manag. 2017, 14, 1-15.

17. Karnama, A. ENERGY X. 0: Future of energy systems. Results Eng. 2019, 3, 100029. [CrossRef]

18. Seo, M.-G.; Hill, N.S. Understanding the human side of merger and acquisition: An integrative framework. J. Appl. Behav. Sci. 2005, 41, 422-443. [CrossRef]

19. Yao, C.-Y.; Shang, S.S.; Yu, Y.-C. The retention of customer relationships after mergers and acquisitions. Corp. Manag. Rev. 2016, 36, 65-104.

20. Watts, G.; Cope, J.; Hulme, M. Ansoff's Matrix, pain and gain. Int. J. Entrep. Behav. Res. 1998, 4, $101-111$. [CrossRef]

21. Apple Inc. Apple Annual Report; Apple Inc.: Cupertino, CA, USA, 2019.

22. Schwab, K. The Fourth Industrial Revolution; Crown Publishing Group: New York, NY, USA, 2017.

23. Ashton, T.S. The Industrial Revolution 1760-1830; Oxford University Press: Oxford, UK, 1997.

24. Stigler, G.J. The economies of scale. J. Law Econ. 1958, 1, 54-71. [CrossRef]

25. Hanson, N.W. Economy of scale as a cost factor in financing public schools. Natl. Tax J. 1964, 17, 92-95.

26. Oreskes, N. The scientific consensus on climate change. Science 2004, 306, 1686. [CrossRef]

27. Serafeim, G.; Grewal, J. ESG Metrics: Reshaping Capitalism? Harvard Business School, 21 March 2016; pp. 1-27.

28. Karnama, A. 'Economies of Scale' is a Myth. Available online: https://www.linkedin.com/pulse/economiesscale-myth-ahmad-karnama/ (accessed on 15 October 2020).

29. Karnama, A. Value Crisis. Available online: https://www.linkedin.com/pulse/value-crisis-ahmad-karnama/ (accessed on 15 October 2020).

30. Jessop, B. The political economy of scale. In Globalization, Regionalization and Cross-Border Regions; Springer: Berlin/Heidelberg, Germany, 2002; pp. 25-49.

31. Silberston, A. Economies of scale in theory and practice. Econ. J. 1972, 82, 369-391. [CrossRef]

32. Baumers, M.; Dickens, P.; Tuck, C.; Hague, R. The cost of additive manufacturing: Machine productivity, economies of scale and technology-push. Technol. Forecast. Soc. Chang. 2016, 102, 193-201. [CrossRef]

33. Nisbett, R.E.; Wilson, T.D. The halo effect: Evidence for unconscious alteration of judgments. J. Personal. Soc. Psychol. 1977, 35, 250. [CrossRef]

34. Leuthesser, L.; Kohli, C.S.; Harich, K.R. Brand equity: The halo effect measure. Eur. J. Mark. 1995, 29, 57-66. [CrossRef]

35. Coombs, W.T.; Holladay, S.J. Unpacking the halo effect: Reputation and crisis management. J. Commun. Manag. 2006, 10, 123-137. [CrossRef]

36. Rosenzweig, P. The Halo Effect: ... and the Eight Other Business Delusions that Deceive Managers; Simon and Schuster: New York, NY, USA, 2014.

37. Schmalensee, R. Economies of scale and barriers to entry. J. Political Econ. 1981, 89, 1228-1238. [CrossRef]

38. Panzar, J.C.; Willig, R.D. Economies of scale in multi-output production. Q. J. Econ. 1977, 91, 481-493. [CrossRef] 
39. Chichilnisky, G. Traditional comparative advantages vs. economies of scale: NAFTA and GATT. Econ. Scale NAFTA GATT 1993. [CrossRef]

40. Zyl, V.J.; Miller, B.R.; Parker, A. The Agrarian Structure in Poland: The Myth of Large-Farm Superiority; The World Bank: Washington, DC, USA, 1999.

41. Hirst, P. The global economy-Myths and realities. Int. Aff. 1997, 73, 409-425. [CrossRef]

42. Bednar, C.S. Transforming the Dream: Ecologism and the Shaping of an Alternative American Vision; SUNY Press: Albany, NY, USA, 2012.

43. Barry, J. Rethinking Green Politics: Nature, Virtue and Progress; Sage: Thousand Oaks, CA, USA, 1999.

44. Fowler, J.H.; Kam, C.D. Beyond the self: Social identity, altruism, and political participation. J. Politics 2007, 69, 813-827. [CrossRef]

45. Carroll, A.B. Corporate social responsibility: Evolution of a definitional construct. Bus. Soc. 1999, 38, $268-295$. [CrossRef]

46. Karnama, A. Organic Growth Theory. Available online: https://www.linkedin.com/pulse/organic-growththeory-ahmad-karnama (accessed on 15 October 2020).

47. Maslow, A.H. Motivation and Personality; Harper \& Brothers: New York, NY, USA, 1954.

48. Maslow, A.H. A theory of human motivation. Psychol. Rev. 1943, 50, 370-396. [CrossRef]

49. Code, L. Ecological Thinking: The Politics of Epistemic Location; Oxford University Press: Oxford, UK, 2006.

50. Maslow, A.H. A Dynamic Theory of Human Motivation. In Understanding Human Motivation; Maslow, A., Stacey, H., Chalmers, L., DeMartino, M., Eds.; Howard Allen Publishers: Cleveland, OH, USA, 1958.

51. Maslow, A.H. Motivation and Personality, 3rd ed.; Harper \& Row Publishers: New York, NY, USA, 1987.

52. Chapman, A. Adapted 7 Level Hierarchy of Needs Diagram Based on Maslow's Theory. Available online: https://www.businessballs.com/maslowhierarchyofneeds7.pdf (accessed on 15 October 2020).

53. Abro, M.M.Q.; Khurshid, M.A.; Aamir, A. Corporate social responsibility (CSR) practices: The case of Saudi Aramco. J. Compet. Stud. 2016, 24, 79.

54. Kearins, K.; Collins, E.; Tregidga, H. Beyond corporate environmental management to a consideration of nature in visionary small enterprise. Bus. Soc. 2010, 49, 512-547. [CrossRef]

55. Schaltegger, S.; Burritt, R. Corporate Sustainability; Edward Elgar: Hamburg, Germany, 2005.

56. Crane, A.; Matten, D.; Moon, J. Ecological Citizenship and the Corporation: Politicizing the new corporate environmentalism. Organ. Environ. 2008, 21, 371-389. [CrossRef]

57. Esbjörn-Hargens, S. An ontology of climate change. J. Integral Theory Pract. 2010, 5, 143-174.

58. Esbjorn-Hargens, S.; Zimmerman, M.E. Integral Ecology: Uniting Multiple Perspectives on the Natural World; Shambhala Publications: Boulder, CO, USA, 2011.

59. Karnama, A.; Peças Lopes, J.A.; Augusto da Rosa, M. Impacts of Low-Carbon Fuel Standards in Transportation on the Electricity Market. Energies 2018, 11, 1943. [CrossRef]

60. Bhattacharyya, S.S.; Verma, S. The intellectual contours of corporate social responsibility literature. Int. J. Sociol. Soc. Policy 2020. [CrossRef]

61. Grover, P.; Kar, A.K.; Ilavarasan, P.V. Impact of corporate social responsibility on reputation-Insights from tweets on sustainable development goals by CEOs. Int. J. Inf. Manag. 2019, 48, 39-52. [CrossRef]

62. Li, X.; Wang, Y.; Zhang, Y.; Cao, Y. Examining the Role of Corporate Social Responsibility in Resident Attitude Formation: A Missing Link? J. Travel Res. 2019, 58, 1105-1122. [CrossRef]

63. Ntanos, S.; Kyriakopoulos, G.; Skordoulis, M.; Chalikias, M.; Arabatzis, G. An application of the new environmental paradigm (NEP) scale in a Greek context. Energies 2019, 12, 239. [CrossRef]

64. De Silva, K.M.; Lokuwaduge, C.S.D.S. Impact of corporate social responsibility practices on employee commitment. Soc. Responsib. J. 2019. [CrossRef]

65. Muda, I.; Sidauruk, H.; Siregar, H.S. The Effect of Corporate Social Responsibility on Company's Value with Common Effects Model (CEM), Fixed Effects Model (FEM) and Random Effects Model (REM) Approaches (Empirical Evidence in Indonesia Stock Exchange). Qual. Access Success 2018, 19, 79-90.

66. Dash, M.K. Corporate Social Responsibility (CSR) and Entrepreneurship in India: Exploring the Landscape of Possibilities. In Implementing Corporate Social Responsibility; Springer: Berlin/Heidelberg, Germany, 2014; pp. 85-100.

67. Betancourt, D.S. Exporting corporate social responsibility into Africa? The experiences of South African companies in Swaziland. J. Contemp. Afr. Stud. 2016, 34, 538-556. [CrossRef] 
68. Kumar, P.V. Corporate social responsibility initiatives for promotion of public libraries. Desidoc J. Libr. Inf. Technol. 2013, 33, 29-31. [CrossRef]

69. Lingard, H.; Blismas, N.; Stewart, P. Corporate social responsibility in the Australian construction industry. Corp. Soc. Responsib. Constr. Ind. 2013, 11, 351.

70. Battaglini, M.; Rasmussen, S. Transparency, automated decision-making processes and personal profiling. J. Data Prot. Priv. 2019, 2, 331-349.

71. Vinuesa, R.; Theodorou, A.; Battaglini, M.; Dignum, V. A Socio-Technical Framework for Digital Contact Tracing. Available online: https://arxiv.org/ftp/arxiv/papers/2005/2005.08370.pdf (accessed on 15 October 2020).

72. Farooq, Q.; Fu, P.; Ahmad, S.; Zhang, Y.; Hao, Y. Assessing human factor in the adoption of computer-based information systems as the internal corporate social responsibility. Sage Open 2019, 9, 2158244019868858. [CrossRef]

73. Kyriakopoulos, G. Half a century of management by objectives (MBO): A review. Afr. J. Bus. Manag. 2012, 6, 1772-1786.

74. Karnama, A. Fruits of Capitalism to Adapt Ecologism. Available online: https://www.linkedin.com/pulse/ fruits-capitalism-adapt-ecologism-adam-karnama (accessed on 15 October 2020).

75. Hinich, M.J.; Munger, M.C. Analytical Politics; Cambridge University Press: Cambridge, UK, 1997.

76. Ross, I.S. The Life of Adam Smith; Oxford University Press: Oxford, UK, 2010.

Publisher's Note: MDPI stays neutral with regard to jurisdictional claims in published maps and institutional affiliations.

(C) 2020 by the authors. Licensee MDPI, Basel, Switzerland. This article is an open access article distributed under the terms and conditions of the Creative Commons Attribution (CC BY) license (http://creativecommons.org/licenses/by/4.0/). 